\title{
Health situation in the perception of elderly widows assisted by primary health care
}

\author{
Situação de saúde na percepção de idosas viúvas assistidas pela atenção primária à saúde \\ Situación de salud en la percepción de viudas ancianas asistidas por la atención primaria de salud
}

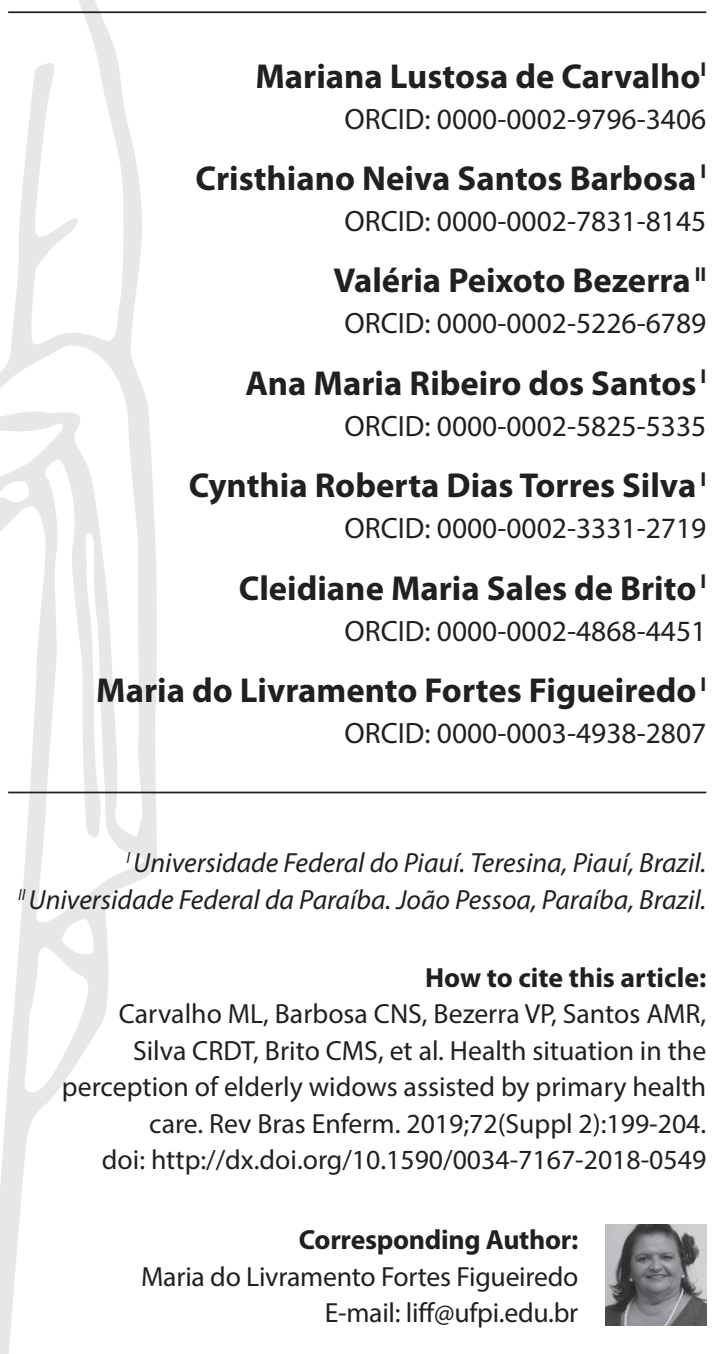

Submission: 06-30-2018 Approval: 03-02-2019

\begin{abstract}
Objective: Analyze the perception of elderly widow women about their health situation. Method: Descriptive and exploratory research, based on qualitative approach performed with 34 widowed women aged 60 years and over, enrolled in primary health care. It was used content analysis in its thematic analysis modality. Results: Three thematic nuclei were obtained: "positive self-perception of health in old age", "negative understanding of health related to the diseases" and "negative repercussions of the absence of the husband in the health situation of the widows". Presence of the family, chronic diseases under control, physical limitations and absence of the partner directly influenced the responses of the elderly widows. Final considerations: The elderly widows perceive their health situation as relatively good and some factors are challenges to a better health situation. For the participants, widowhood means more than just the physical loss of the husband, interfering negatively in the perception of their health situation.

Descriptors: Women, Widowhood; Aged; Perception; Primary Health Care.
\end{abstract}

\section{RESUMO}

Objetivo: Analisar a percepção de mulheres idosas viúvas sobre sua situação de saúde. Método: Pesquisa descritiva e exploratória, baseada na abordagem qualitativa realizada com 34 mulheres viúvas com idade igual ou superior a 60 anos, cadastradas na atenção primária à saúde. Utilizou-se da análise de conteúdo em sua modalidade análise temática. Resultados: Foram obtidos três núcleos temáticos: "a autopercepção positiva da saúde na velhice", "compreensão negativa da saúde relacionada aos agravos" e "repercussões negativas da ausência do companheiro na situação de saúde das viúvas". Presença da família, doenças crônicas sob controle, limitações físicas e ausência do companheiro influenciaram diretamente as respostas das idosas viúvas. Considerações finais: As idosas viúvas percebem sua situação de saúde como relativamente boa e alguns fatores são desafios a uma melhor situação de saúde. Para as participantes, a viuvez significa mais que apenas a perda física do cônjuge, interferindo negativamente na percepção de sua situação de saúde.

Descritores: Mulheres; Viuvez; Idosas; Percepção; Atenção Primária à Saúde.

\section{RESUMEN}

Objetivo: Analizar la percepción de la mujer viuda anciana acerca de su propia situación de salud. Método: Investigación descriptiva y exploratoria, basada en el enfoque cualitativo realizado con 34 mujeres viudas de al menos 60 años, inscritas en la atención primaria de salud. Se utilizó análisis de contenido en su modalidad de análisis temático. Resultados: Se obtuvieron tres núcleos temáticos: "autopercepción positiva de la salud en la vejez", "comprensión negativa de la salud relacionada con las enfermedades" y "repercusiones negativas de la ausencia de la pareja en la situación de salud de las viudas". La presencia de la familia, las enfermedades crónicas bajo control, las limitaciones físicas y la ausencia de la pareja influyeron directamente en las respuestas de las viudas ancianas. Consideraciones finales: Las viudas ancianas perciben que su situación de salud es relativamente buena y algunos factores son desafíos para mejorar la situación de la salud. Para las participantes, la viudez significa más que solo la pérdida física del esposo, lo que interfiere negativamente en la percepción de su situación de salud.

Descriptores: Mujeres; Viudez; Anciano; Percepción; Atención Primaria de Salud. 


\section{INTRODUCTION}

The process of ageing population occurs through the constant increase of the years of life associated with the drop in fertility and mortality, and can be defined as a multifaceted process throughout the entire life course $\mathrm{e}^{(1-2)}$.

According to official data, in Brazil, the old age population rose from $9.7 \%$ in 2004 to $14.3 \%$ in 2015 , of that $8 \%$ is represented by the female contingent of more than 60 years ${ }^{(3)}$, implying the feminization of old age $\mathrm{e}^{(4-5)}$.

This greater female longevity, that is approximately eight years longer than the male sex in Brazil, is explained in several conditions, among them, the high levels of estrogen, that provide greater protection. In addition, women are generally less susceptible to factors that cause mortality, such as accidents and violence. It is important to emphasize the attitude towards the health disease process, considering that women seek health services more frequently, showing greater attention to self-care ${ }^{(2,5)}$.

Female predominance in the aged group brings several positive and/or negative factors both for the woman and for the family, since it may be associated with a greater social risk and with the restructuring of the relational space too, because the elderly woman is an important link to the family support network ${ }^{(6)}$.

Moreover, the increase in the representativeness of this female population is accompanied by the prevalence of widowhood among the elderly women. Since instead of seeking new relationships, they begin to perform more expressively activities related to interpersonal care, such as caring for grandchildren and great-grandchildren. In addition to the attention given to their own health, considering as relevant moments of leisure in their social context, to the detriment of plans or longings for conjugal relationships ${ }^{(7)}$.

Thus, the process of feminization of old age is associated with female widowhood, that leads to changes in social life, such as move, live with sons, practicing different activities or stop to perform activities that they did with their partners, beyond the suffering represented by "emotional losses", because they are related to the death of close relatives ${ }^{(6,8)}$.

In this context, the status of widowhood can be represented in different ways and have different health effects, since the lives of these elderly women are based on social relations that are developed in different contexts, in the relationship with the husband, the sons and other family members, as well as friends and informal interactions. This condition may still have repercussions on the health of these women, considering the historical and cultural aspects that involve gender issues.

According to this, the elderly women can perceive widowhood in different ways, so that they can understand the death of their husbands as tragedy or liberation. This is confirmed in many studies, in which it was observed that for some elderly women widowhood proved to be tragic and could trigger damage that persists over time $\mathrm{e}^{(9)}$. For others, widowhood is freedom and independence: many of them were mistreated by their husbands and suffered from social isolation during marriage. In this way, widowhood means autonomy for the elderly women, since in their youth or adult life they did not have freedom because of the gender relations prevalent in past ${ }^{(10)}$.
Thus, according to the experiences, the elderly women can elucidate the aging and the pathological processes in different ways, covering physical, psychic, emotional, social, demographic and socioeconomic aspects, in addition to the social context in which they live. The perception of health, in other words, how the elderly women understand their own health, is considered an important factor of expression of the loss of functional capacity. The support of family and friends and the feeling of being useful, interacting with others, is a way of minimizing the loss suffered by the aging, and is possible to them to understand this period in different ways $s^{(6,11)}$.

\section{OBJECTIVE}

Analyze the perception of elderly women widows about their health situation.

\section{METHOD}

\section{Ethical aspects}

This study was initiated after approval by the Research Ethics Committee (Comitê de Ética em Pesquisa - CEP) and linked to a research project approved by the CEP of the Universidade Federal do Piauí (UFPI). All the participants were informed about the research and signed the Informed Consent Form (Termo de Consentimento Livre e Esclarecido).

\section{Methodological theoretical reference and type of study}

A qualitative study, descriptive and exploratory, that used as theoretical reference the analysis of content, thematic analysis type, for evaluation of the data ${ }^{(12)}$.

\section{Scenario of the study}

This study was carried out in Basic Health Units (Unidades Básicas de Saúde - UBS), in Teresina, capital of Piauí, Northeast of Brazil. The health system of Teresina is currently organized in Regional Health Directories (Diretorias Regionais de Saúde-DRS). The health system of Teresina is currently organized in Regional Health Directories (DRS), spatially divided in the geographical territory of the city and covering the service of the population assigned in three large macro spaces: DRS Centro / Norte, East / Southeast DRS and Southern DRS. Each DRS is composed of several UBS, in which the groups of the Family Health Strategy (ESF) work. The study ensured the representativeness of participants of the three DRS mentioned above.

The three SDRs provide coverage to 620,098 people, of whom 74,022 are people 60 years of age or older, 43,495 women, corresponding to $58.7 \%$ of the people in this age group and 15,755 women in this group are widows ${ }^{(13)}$.

The study included elderly widows registered in ESF, who had favorable cognitive conditions to answer the questioning, related to self-perception of health. In order to preserve the anonymity of the participants involved in the study, we used during the discussion of the research the identification by the word "widow", followed by the numerical ordering of each report (Widow 1, Widow 2, Widow 3 ...). 
The elderly women with incomplete addresses in the registry of the basic health units and who did not have enough cognitive capacity to understand and respond to the interview were excluded from the sample, the elderly women who did not reach the minimum score set by Bertolucci et $\mathrm{al}^{(14)}$ that considers different cutoff points for schooling.

The number of participants interviewed was determined by the criterion of data saturation, finalizing the insertion of new members when the data came to expose redundancy or recurrence, besides to adding little information to the material already obtained ${ }^{(15)}$. The sample was completed with 34 widowed women aged 60 years or older, by random selection of the participants in each DRS. The study was carried out in the women's homes, because it allows better access of the researchers to the participants of the investigation and the home offers greater comfort and comfort to the investigated group.

\section{Collection and organization of data}

The data collection was carried out in the months of March and April of 2016. We used two instruments: the first was the Mini-mental State Examination (MMSE), to evaluate the participants' cognitive status and then to define the members apt to compose the sample, and the second was a form containing an open question about the situation of the participants.

In this last stage, the verbal answer of each of the elderly widows was recorded by means of an MP3 player, with their authorization. After the interview, we transcribed the audio and made the first reading of the material, mapping and grouping the reports into thematic nuclei.

\section{Data analysis}

The talking were submitted to thematic analysis, following the phases of pre-analysis, material exploration, treatment of the results obtained and interpretation ${ }^{(12)}$. After exploring the information, three thematic categories were revealed: positive self-perception of health in old age, negative understanding of health related to the diseases and negative repercussions of the absence of the husband in the health situation of the widows.

\section{RESULTS}

The elderly women interviewed were in the age range of 60 to 92 years, the sample mean was 74 years; 18 (52.9\%) had income derived mainly from pension, receiving on average one and two minimum wages, and $25(73.5 \%)$ of them were born in rural areas. Regarding color or race, 24 (70.5\%) of them declared themselves as brown skin, so that three generations family arrangement predominated, that is, 18 (52.9\%) elderly widows of the study live with their sons and grandchildren.

In terms of schooling, 18 (52.9\%) participants stated that they were illiterate. Regarding the alcohol habit, two of them reported using alcohol. Regarding the health of the interviewees, we identified that the participants of the study are carriers of some clinical pathologies, especially arterial hypertension (24/70.5\%), anxiety (18/52.9\%), osteoporosis (17/50\%), diseases of the cardiovascular system (14 / 41.1\%) and diabetes (10 / 29.4\%).
Concerning to the treatment and analysis of the speeches about the health situation of the elderly widows of the study, we obtained three thematic nuclei: positive self-perception of health in old age, negative understanding of health related to the diseases and negative repercussions of the absence of the husband in the health situation of the widows.

\section{Positive self-perception of the health situation}

In this thematic category, we sought to describe the positive perceptions that the interviewees have regarding the general context of their lives related to the health standard. Twenty six interviewees presented speeches that refer to a good or excellent health situation and related this condition to the presence of the family or to the control of their own diseases. In this connection, according to the reports described below, we observed the relevance of the family to the perception of the elderly woman:

My health is good, I think. I do my things by myself; I have my sons to help me and to be with me. They accompany me to the doctor when I need them, and sometimes I travel with them [...] I am happy because I have my sons with me. (Widow 22)

I'm fine, and I think my health is very good because whenever I need my grandchildren are here and at night my sons come and stay here with me too. When everyone is around, we feel happy, right? (Widow 23)

More than the reports mentioned above, we also verified that some elderly women evaluated their health situation positively related to the fact that they perceived that the pre-existing chronic diseases are under control, according to the narratives below:

It is good, because even with the problems in the legs, I use the right medicines and then it is controlled, different from some neighbors who have more serious illnesses. (Widow 13)

It is not excellent because I am diabetic, hypertensive and not much worse because there are others elderly women who are prostrate, and my diseases are controlled. (Widow 15)

I do not have these serious diseases, only osteoporosis, but it is possible to live well. (Widow 24)

\section{Negative self-perception of health related to the presence of chronic diseases}

In the face of the various chronic diseases and health problems reported by elderly women, there was a strong relationship between a negative understanding of health and the presence of chronic diseases. Eight interviewees reported having a "bad" and "very poor" health condition, relating this situation to chronic diseases, as well as to the physical difficulties and limitations caused by these pathologies.

It's bad because I have a lot of diseases. Osteoarthritis hurts a lot, and because of diabetes I cannot eat what I want. This is bad, right? A person cannot live well having so many diseases like that. (Widow 25) 
It's too bad, because I do not do anything else because of illness. This problem in my back, the pressure, diabetes, and in the bones. This way, with so many diseases, I feel a lot of pain, and even with medicines I still feel. It's hard to live like this, because I cannot do my simple everyday things anymore, and I'm depending on others to do things in my home. (Widow 27)

It is possible to notice that in the conception of these elderly women, the presence of chronic diseases is fundamental in the formulation of the perception about their own health situation. Moreover, the interviewees point out that the limitations resulting from these pathologies are a negative influence in their health situation.

\section{Negative repercussions of the absence of the husband in the widows' health situation}

It was notorious that the absence of the husband also had an impact on the health of these elderly women, because it was a study about widows. The experience of mourning, even after years, still shows consequences in the life and health of these women, mainly because they had long-lasting relationships, with the bond strengthened between the couple.

If I had him, I think I was more happy [...] because I never forgot him. (Widow 2)

He died and I was alone [...] I ended up getting this way, with a serious problem that appeared in me, and they had nothing to do with me and took my legs. (Widow 14)

Facing and overcoming the death of the husband depends on the context in which the person in mourning lives, and can be manifested in different ways. The absence of the husband's figure has had negative consequences on the perception of some elderly women about their health. It is evidenced by the loneliness and the lack of someone to help even in domestic tasks, besides the development of physical problems, as reported by the participant Widow 14 .

\section{DISCUSSION}

The results show the interface between the health perception of the elderly women and the context in which they live, with emphasis on the factors that may motivate the positive or negative evaluation of health, such as family presence, chronic diseases with consequent limitations and death of their husbands.

The presence of the family influences the way the elderly widows contemplate their health and it is the reason why many of the interviewees justified the cause for their health being "good" or "excellent."Therefore, it is clear that family's attitudes are indispensable and relevant to the care and health of the elderly women. It is worth mentioning that, even though it is the duty of the family to support the elderly through informal care, but the family do not benefited, protect and care all of them ${ }^{(16-17)}$.

These reports corroborate the findings of a study carried out with 20 elderly people living in Chapecó, Santa Catarina, in which all the participants attributed their happiness or sadness conditions directly to their family relationships, showing that, in this stage of life, the family gains greater value and meaning for the ageing ${ }^{(17)}$.
Judging a good health situation when comparing with that of other elderly women influences the way of seeing the peculiar condition in which each elderly woman lives, since a greater number of chronic diseases not controlled in the context of the lives of other widows reduces the quality of life and changes the standard of health ${ }^{(18)}$.

A study with elderlies in Florianópolis observed that the lower number of pathologies, or even nonexistence, increased the optimistic health evaluation indexes. The fact that individuals who have explained one or two long-lasting illnesses are more apt to keep them under control and therefore are judged to be healthy, reflecting a positive assessment about their health, explains this finding ${ }^{(19)}$. It can be inferred, therefore, that family life and the correct treatment of chronic diseases make the elderly women presume their health situation as good.

Some studies observed that disease involvement is directly related to the perception of a bad health, and the high number of pathologies shows a higher prevalence of negative health evaluation. In addition, worse indices of quality of life and health situation and the inability to perform activities of daily life are verified in elderly people who have a quantitative of three or more diseases that causes consequent impairment of functional capacity. Faced with these factors, the elderly women who have three or more diseases judge their own health in an unfavorable way ${ }^{(17,20)}$, which is proven in the interviewees' speeches.

The existence of restriction to perform the instrumental activities of daily life influences how the elderly woman understand their health condition. Dependence, with physical restraints and frailties may indicate a negative evaluation of one's health suggesting that decline in functional capacity is a parameter used by individuals to rate health in old age ${ }^{(4,21)}$.

If the level of dependency and the limitations increase, due to the diseases accumulated along the old age, the probability of the elderly person to have a less optimistic perception of the health with respect to the functional capacity is greater. Thus, the loss of autonomy manifests as a new paradigm of vitality and becomes one of the main determinants of the understanding of the health situation of the elderlies. With functional capacity compromised because of chronic diseases, the limitations arise and hinder the elderly women to carrying out daily activities, what consequently is negatively associated with the health situation ${ }^{(4)}$.

In addition, polypharmacy and a high number of comorbidities are constantly related in the worst perceptions of health. The existence of these pathologies is an important predictor of limitations and obstacles for the individual to take care of himself, and is a significant variable for the association with negative health self-assessment ${ }^{(19,21)}$.

Losing the husband can be harrowing in any age. Considering that the elderly couple has an extended previous life, the impact of mourning has a great extent and can be devastating. The involvement of the woman in mourning, the reasons for the death, the strength and the affective bond, the trust and the conjunction of the particular relationship between the couple are factors for the prediction of how the emotional process will unfold in the person who is the victim of the conjugal loss. These factors can influence directly the way in which the elderly women perceive their health ${ }^{(8,22)}$.

In this context, widowhood influence in the health of the elderly women is highlighted, since the demand for health services 
increases, mainly because they are fragile. The situation of loneliness, with the absence of the husband, increases the number of hospitalizations in nursing homes, rest homes and hospitals, with consequent mortality due to illness. In addition, with the loss of the husband, the elderly women may face the isolation and feeling of being alone, not only because of the absence of the husband's support, but because of the mishaps faced as a result of becoming the head of the family, with the responsibilities of managing the house and the family life ${ }^{(22)}$.

With the absence of the husband, the elderly woman often go through a remodeling of the concept related to the gender issues previously perceived, mainly due to the changes suffered in the social attributions after the widowhood, being imposed the need to rethink and reformulate their position, assuming the new reality, with new functions, autonomy and new learning $^{(23)}$. The insecurity because of the new routine demonstrates as a predictor for the feelings that influence the elderly woman's perception of the health after the death of the husband.

As today's elderly women were excluded from activities in public and political life, marriage was the only way to seize economic security and satisfactorily respond to social impositions. After the death of the husband, the tendency for these women is to transfer to the family the obedience and dependence previously assigned to the husband, maintaining the social determinations and reinforcing the feminine submission ${ }^{(23-24)}$.

Although most elderly women perceive their health condition as "excellent" and "good", it is important to consider that widowhood may subject women to isolation and less health concern and, consequently, negatively influence functional capacity, generating a more pessimistic self-perception of health.

The type of relationship experienced by these women with their husbands prior to widowhood should influence different ways of perceiving their health condition. A study carried out with elderly women highlights different ways of perceiving widowhood because of the relationship with the husband, since for some women the status of widowhood was positive in face of conflicting conjugal experience, for others this phase was attributed as negative because of social and emotional difficulties due to the loss suffered ${ }^{(6)}$. For the women who have assigned the status of widowhood as positive, the consequences on their health for the conflictual relationship with the husband may be setting themselves up as an invisible process at present, but with measurable implications over the years.

Thus, the loss of the husband may have negative repercussions on the elderly women's health and interfere with the way that they describes their health situation. The absence of the husband impacts on the well-being of these women, especially the discouragement and isolation felt at this stage, causing disinterest in self-care and consequent loss of autonomy ${ }^{(25)}$.

\section{Limitations of the study}

This study presents some inherent limitations to the methodological approach adopted, not allowing generalizations due to the small number of subjects or because of the performance in only one Brazilian region. Most of our sample was composed of illiterate elderly women, which make it difficult to them to understand the study's questions and thus contribute to the bias of the results. It is also worth mentioning that the application of the MMSE, to assess the cognitive status of the participants, using schooling as a criterion for establishing cutoff points, may be influenced by the predominant degree of education in the sample (illiterate).

\section{Contributions to the area of nursing, health or public policy}

Knowing the perception that elderly widows have about their own health allows nurses to act in the planning and implementation of actions and care in the perspective of health promotion, considering their experiences and understandings. In addition, it reaffirms the repercussion of widowhood in the life of these elderly women, offering support for greater care based on the needs of this population. These professionals, especially in primary care, are one of the key elements for the development of better health situations for this elderly, seeking plausible interventions based on the subjectivity and singularity of each elderly woman.

\section{FINAL CONSIDERATIONS}

We identified that elderly widows perceive their health status as relatively good in the overall context of life. Some factors challenge a better health situation, namely: the presence of chronic diseases and their limitations associated with the absence of the husband. For the participants, widowhood means more than just the physical loss of the husband, representing, in the history of the elderly women, the emergence of important difficulties, capable of interfering negatively in the perception of their health situation.

\section{FUNDING}

Conselho Nacional de Desenvolvimento Científico e Tecnológico (CNPq).

\section{REFERENCES}

1. Barcelos RA, Tavares DMS. Factors associated with patient safety incidents among elderly people in intensive care. Acta Paul Enferm [Internet]. 2017 [cited 2017 Aug 16];30(2):159-67. Available from: http://dx.doi.org/10.1590/1982-0194201700025

2. Sousa AFL, Queiroz AAFLN, Oliveira LB, Moura LKB, Andrade D, Watanabe E, et al. Deaths among the elderly with ICU infections. Rev Bras Enferm [Internet]. 2017 [cited 2017 Aug 16];70(4):733-39. Available from: http://dx.doi.org/10.1590/0034-7167-2016-0611

3. Instituto Brasileiro de Geografia e Estatística-IBGE. Pesquisa Nacional por Amostra de Domicílio: síntese de indicadores 2015. Coordenação de Trabalho e Rendimento. [Internet]. Rio de Janeiro. 2016 [cited 2017 Nov 25]. Available from: https://biblioteca.ibge.gov.br/visualizacao/ livros/liv98887.pdf 
4. Pereira LV, Figueiredo MLF, Beleza CMF, Andrade EMR, Silva MJ, Pereira AFM. Predictors for the functional incapacity of the elderly in primary health care. Rev Bras Enferm [Internet]. 2017 [cited 2017 Aug 16];70(1):112-18. Available from: http://dx.doi. org/10.1590/0034-7167-2016-0046

5. Santos GS, Cunha ICKO. Avaliação da qualidade de vida de mulheres idosas na comunidade. R Enferm Cent O Min [Internet]. 2014 [cited 2017 Aug 16];4(2):1135-45. Available from: http://www.seer.ufsj.edu.br/index.php/recom/article/view/593/749

6. Almeida AV, Mafra SCT, Da Silva EP, Kanso S. A Feminização da velhice: em foco as características socioeconômicas, pessoais e familiares das idosas e o risco social. Textos Contextos [Internet]. 2015 [cited 2017 Aug 16];14(1):115-31. Available from: http://revistaseletronicas.pucrs.br/ ojs/index.php/fass/article/view/19830

7. Melo NCV, Teixeira KMD, Barbosa TL, Montoya AJA, Silveira MB. Household arrangements of elderly persons in Brazil: analyses based on the national household survey sample (2009). Rev Bras Geriatr Gerontol. 2016;19(1):139-51. doi: 10.1590/1809-9823.2016.15011

8. Turatti BO. Implicações da viuvez na saúde: uma abordagem fenomenológica em Merleau-Ponty. Saúde Transform Soc [Internet]. 2013 [cited 2017 Aug 16];3(1:32-8. Available from: http://pepsic.bvsalud.org/pdf/sts/v3n1/v3n1a06.pdf

9. Baldin CB, Fortes VLF. Viuvez feminina: a fala de um grupo de idosas. RBCEH [Internet]. 2008 [cited 2018 Jul 20];5(1):43-54. Available from: http://seer.upf.br/index.php/rbceh/article/view/257/192

10. Rubio ME, Wanderley KS, Ventura MM. A viuvez: a representação da morte na visão masculina e feminina. Rev Kairós [Internet] 2011 [cited $2018 \mathrm{Jul}$ 30];14(1):137-47. Available from: https://revistas.pucsp.br/index.php/kairos/article/view/6932

11. Borges AM, Santos G, Kummer JA, Fior L, Molin VD, Wibelinger LM. Autopercepção de saúde em idosos residentes em um município do interior do Rio Grande do Sul. Rev Bras Geriatr Gerontol [Internet]. 2014 [cited 2017 Aug 16];17(1):79-86. Available from: http://dx.doi. org/10.1590/S1809-98232014000100009

12. Minayo MCS. O desafio do conhecimento: pesquisa qualitativa em saúde. 13th ed. São Paulo: Hucitec; 2013.

13. Ministério da Saúde. (BR). Departamento de Informática do Sistema Único de Saúde (Datasus). Sistema de Informação de Atenção Básica (Siab) [Internet]. Brasília: Ministério da Saúde; 2014[cited 2017 Aug 16]. Available from: http://dab.saude.gov.br/portaldab/siab.php

14. Bertolucci PH, Brucki SM, Campacci SR, Juliano Y. O mini-exame do estado mental em uma população geral: impacto da escolaridade. Arq Neuropsiquiatr [Internet]. 1994 [Cited 2018 Jul 27];52:1-7. Available from: http://www.scielo.br/pdf/anp/v52n1/01.pdf

15. Fontanella, BJB, Magdaleno Jr, R. Saturação teórica em pesquisas qualitativas: contribuições psicanalíticas. Psicol Estud [Internet]. 2012 [cited 2017 Nov 25];17(1):63-71. Available from: http://dx.doi.org/10.1590/S1413-73722012000100008

16. Xu L, Li Y, Min J, Chi I. Worry about not having a caregiver and depressive symptoms among widowed older adults in China: the role of family support. Aging Ment Health[Internet]. 2017 [cited 2017 Dec 10];21(8):879-88. Available from: https://www.ncbi.nlm.nih.gov/ pubmed/27166663

17. Ascari RA, Comiran DF, Farias AAP, Correio LEF. A percepção do idoso acerca das atividades sociais e saúde. Estud Interdiscipl Envelhec [Internet]. 2015 [cited 2017 Oct 29];20(1):103-19. Available from: http://www.seer.ufrgs.br/RevEnvelhecer/article/view/44652

18. Pezzin LE, Pollak RA, Schone BS. Complex families and late-life outcomes among elderly persons: disability, institutionalization, and longevity. J Marriage Fam [Internet]. 2013 [cited 2017 Oct 29];75(5):1084-97. Available from: https://www.ncbi.nlm.nih.gov/ pubmed/24031097

19. Confortin SC, Giehl MWC, Antes DL, Schneider IJC, d'Orsi E. Positive self-rated health in the elderly: a population-based study in the South of Brazil. Cad Saúde Pública [Internet]. 2015 [cited 2017 Aug 17];31(5):1049-60. Available from: http://dx.doi.org/10.1590/0102-311X00132014

20. Pavão ALB, Werneck GL, Campos MR. Self-rated health and the association with social and demographic factors, health behavior, and morbidity: a national health survey. Cad Saúde Pública [Internet]. 2013 [cited 2017 Aug 17];29(4):723-34. Available from: http://dx.doi. org/10.1590/S0102-311X2013000400010

21. Silva RJS, Smith-Menezes A, Tribess S, Rómo-Perez V, Virtuoso Jr JS. Prevalência e fatores associados à percepção negativa da saúde em pessoas idosas no Brasil. Rev Bras Epidemiol [Internet]. 2012 [cited 2017 Aug 17];15(1):49-62. Available from: http://dx.doi.org/10.1590/ S1415-790X2012000100005

22. Farinasso ALC, Labate RC. The bereavement experience in elderly widows: a clinical-qualitative study [Internet]. 2015 [cited 2017 Aug 17];11(1):25-32. Available from: http://dx.doi.org/10.11606/issn.1806-6976.v11i1p25-32

23. Fernandes MGM. Social roles of gender in the olg age: the look of yourself and of the other. Rev Bras Enferm [Internet]. 2009 [cited 2017 Oct 31];62(5):705-10. Available from: http://dx.doi.org/10.1590/\$0034-71672009000500009

24. Souza M, Marcon SS, Bueno SMV, Carreira L, Baldissera VDA. [Elderly widows' experience of sexuality and their perceptions regarding the family's opinion]. Saúde Soc [Internet]. 2015 [cited 2017 Oct 31];24(3):936-44. Available from: http://dx.doi.org/10.1590/S010412902015132060 Portuguese

25. Soares MBO, Tavares DMS, Dias FA, Diniz MA, Geib S. Morbidades, capacidade funcional e qualidade de vida de mulheres idosas. Esc Anna Nery [Internet]. 2010 [cited 2017 Aug 17];14(4):705-11. Available from: http://dx.doi.org/10.1590/S1414-81452010000400008 